Article

\title{
Successional Variation in the Soil Microbial Community in Odaesan National Park, Korea
}

\author{
Hanbyul Lee ${ }^{1}$, Seung-Yoon $\mathrm{Oh}^{2}{ }^{\circledR}$, Young Min Lee ${ }^{1}$, Yeongseon Jang ${ }^{3}$, Seokyoon Jang ${ }^{1}$, \\ Changmu Kim ${ }^{4}$, Young Woon Lim ${ }^{5, *}$ (i) and Jae-Jin Kim ${ }^{1, *(1)}$ \\ 1 Division of Environmental Science \& Ecological Engineering, College of Life Sciences \& Biotechnology, \\ Korea University, Seoul 02841, Korea; hblee95@korea.ac.kr (H.L.); ymlee25@korea.ac.kr (Y.M.L.); \\ skel@korea.ac.kr (S.J.) \\ 2 Department of Biology and Chemistry, Changwon National University, Changwon 51140, Korea; \\ syoh@changwon.ac.kr \\ 3 Division of Special Forest Production, National Institute of Forest Science, Seoul 02455, Korea; idjys@korea.kr \\ 4 Microorganism Resources Division, National Institute of Biological Resources, Incheon 22689, Korea; \\ snubull@korea.kr \\ 5 School of Biological Sciences and Institute of Microbiology, Seoul National University, Seoul 08826, Korea \\ * Correspondence: ywlim@snu.ac.kr (Y.W.L.); jae-jinkim@korea.ac.kr (J.-J.K.); \\ Tel.: +82-2-880-6708 (Y.W.L.); +82-2-3290-3049 (J.-J.K.); Fax: +82-2-871-5191 (Y.W.L.); +82-2-3290-9753 (J.-J.K.)
}

Received: 4 May 2020; Accepted: 10 June 2020; Published: 11 June 2020

check for updates

\begin{abstract}
Succession is defined as variation in ecological communities caused by environmental changes. Environmental succession can be caused by rapid environmental changes, but in many cases, it is slowly caused by climate change or constant low-intensity disturbances. Odaesan National Park is a well-preserved forest located in the Taebaek mountain range in South Korea. The forest in this national park is progressing from a mixed-wood forest to a broad-leaved forest. In this study, microbial community composition was investigated using 454 sequencing of soil samples collected from 13 different locations in Odaesan National Park. We assessed whether microbial communities are affected by changes in environmental factors such as water content (WC), nutrient availability (total carbon (TC) and total nitrogen (TN)) and $\mathrm{pH}$ caused by forest succession. WC, TC, TN and $\mathrm{pH}$ significantly differed between the successional stages of the forest. The WC, TC and TN of the forest soils tended to increase as succession progressed, while $\mathrm{pH}$ tended to decrease. In both successional stages, the bacterial genus Pseudolabrys was the most abundant, followed by Afipia and Bradyrhizobium. In addition, the fungal genus Saitozyma showed the highest abundance in the forest soils. Microbial community composition changed according to forest successional stage and soil properties (WC, TC, TN, and $\mathrm{pH}$ ). Furthermore, network analysis of both bacterial and fungal taxa revealed strong relationships of the microbial community depending on the soil properties affected by forest succession.
\end{abstract}

Keywords: bacterial and fungal community; forest soil; microbial network; succession; vegetation

\section{Introduction}

Recently, research on microbial diversity has progressed actively due to the development of high-throughput sequencing (HTS) technology, and the accumulation of many research results has increased the understanding of the microbial community and the sustainability of microbial resources for industrial and commercial applications [1-3]. Over the last decade, studies on the microbial community have focused on measuring the diversity in a given study area and comparing composition and structure between environments [4-6]. In particular, microbial communities of forest soils have been used to investigate the microbial variation caused by vegetation type and altitude and the successional 
changes caused by forest fires, flooding and cleavage [7-9]. These studies have reported that plant compositions and soil properties relate to changes in coil microbial communities [7,9]. Soil organic matter accumulates via litter, deadwood, microbial biomass, other materials, and the accumulated organic matter is further decomposed by microbes [7]. Thus, the main roles of microorganisms in forest soils are decomposition and mineralization of organic matter, and these roles also affect the release of greenhouse gases produced by microbial metabolism $[7,8]$. Therefore, tree identity and soil properties interact closely with the local microbial community [9].

Forest ecosystems continue to change dynamically over time. All ecosystem components, such as climate, terrain, soil, and biomass, change quickly or slowly and are sometimes altered by specific disturbances that reflect location characteristics [10-12]. Succession is the process in which the structure or composition of the ecological community changes over time [13]. The time scale for ecological succession can range from decades to millions of years depending on ecosystem characteristics. In particular, forest succession occurs over decades to thousands of years and is characterized by a series of changes, such as changes in dominant species, vegetation types, and relative abundance [14,15]. Traditional research has focused on changes in plant species and vegetation types because these changes can be easily observed as the forest ecosystem develops and changes [16,17]. In addition, most studies of microbial community variation during succession have focused on allogenic succession caused by external factors, such as fire, insects, and clear-cutting, which have dramatically changed existing ecosystems [18-21]. However, a study of autogenic succession of existing plants revealed that considering this process helps predict the progression of succession over a long period of time, with no rapid variation [22]. In addition, studies on microbial changes during autogenic succession have uncovered differences in the dominance of bacterial and fungal communities in early and late stages [21], an effect of soil temperature on microbial community composition during climate change [23], and the dependence of the community assembly of ectomycorrhizal fungi on vegetation composition [24].

Odaesan National Park is a representative national park with the oldest forest in Korea. The Odaesan National Park area is located in a cool-temperature and deciduous broad-leaved forest zone, considering the relationships between climatic factors and vegetation. Domestic studies on aspects of the vegetation in this park, such as forest community structure, plant community structure, and vegetation structure, have been conducted [25-27]. According to an analysis of the forest community of Odaesan National Park, Abies holophylla, Acer pseudosieboldianum, Lindera obtusiloba, Pinus densiflora, Quercus mongolica, and Quercus variabilis are the dominant species [26,27]. It was reported that the vegetation patterns of the park depended on elevation, moisture content, organic matter content, and total nitrogen content of the forest soil [28]. In addition, via succession, the P. densiflora community mainly found at low elevation is undergoing succession into Q. mongolica and Q. variabilis community, representing succession from mixed-wood to broad-leaved forest [28]. There have been several studies on the natural succession of forests from Pinus spp. dominance to Quercus spp. dominance [29,30]. Studies have identified the height and leaf type of each tree species as reasons for succession, and mature $Q$. mongolica and $Q$. variabilis are taller than P. densiflora and have broad leaves, which inhibit the growth of $P$. densiflora by blocking sunlight $[28,29]$. However, studies of the microbial diversity and their successional shift in Odaesan National Park have rarely been reported in the overall field. Therefore, we examined the microbial succession of Odaesan National Park by bacterial and fungal amplicon analysis of forest soil samples from a total of 13 sites, assuming that the forests in Odaesan National Park were undergoing succession from a mixed-wood forest to a broad-leaved forest. This study aims to reveal differences in soil properties caused by forest succession, the microbial diversity and structure of Odaesan National Park, differences in the microbial community associated with successional stage, and the taxonomic networks of microorganisms developed in each forest. 


\section{Materials and Methods}

\subsection{Description of the Study Sites}

This study was conducted in Odaesan National Park, South Korea $\left(37^{\circ} 42^{\prime}-52^{\prime}\right.$ N $128^{\circ} 28^{\prime}-46^{\prime}$ E). This park was designated in 1975 as the 11th national park of Korea. The major peaks of Mt. Odae include Birobong (1563 m), Dongdaesan (1434 m), Durobong (1422 m), and Sangwangbong $(1493 \mathrm{~m})$. The mean annual temperature is $6.5^{\circ} \mathrm{C}$, with a monthly mean minimum temperature of $-13.8^{\circ} \mathrm{C}$ (December) and monthly mean maximum temperature of $25^{\circ} \mathrm{C}$ (July) in 2013. The annual precipitation is $1288.7 \mathrm{~mm}$, which is mainly concentrated in summer. All meteorological data were collected by the Korea Meteorological Administration from the Daegwallyeong station (http: //www.kma.go.kr/weather/climate/data_monthly.jsp).

\subsection{Soil Sampling}

Soil samples were collected at each stage of succession from 13 different points selected based on elevation and the distance between locations (Figure 1 and Table S1). Samples were collected twice. The first sampling was on 22 April 2013, and the second sampling was on 3 September 2013. Topsoil ( $10 \mathrm{~cm}$ depth) was collected three times using sterile $50-\mathrm{mL}$ conical tubes in a triangular pattern with a 1-m radius at each location. The three soil samples collected from each location were combined and sieved together using $2-\mathrm{mm}$ sieves and frozen at $-80^{\circ} \mathrm{C}$ until use.

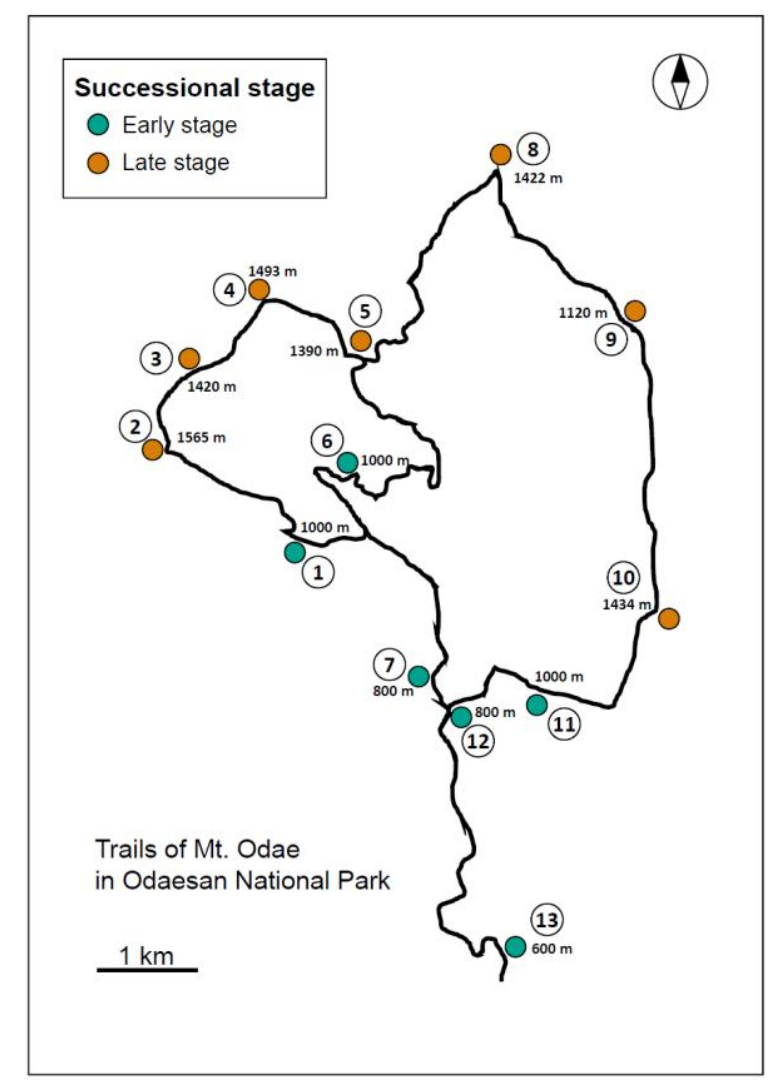

Figure 1. The 13 soil sample locations in Odaesan National Park.

\subsection{Analysis of Soil Properties}

Each soil sample was dried in an oven at $105^{\circ} \mathrm{C}$ for 1 day, and the soil water content (WC) was measured. Soil $\mathrm{pH}$ was measured in a 1:5 dilution of soil:distilled water using an Orion $3 \mathrm{Star} \mathrm{pH}$ meter equipped with an Orion 8157 BNUMD probe (Thermo Scientific, Beverly, MA, USA). Soil total carbon (TC) and total nitrogen (TN) contents were measured by a Flash EA 1112 elemental analyzer 
(Thermo Elemental, Waltham, MA, USA). Differences in soil properties between successional stages were assessed using the Wilcoxon rank sum test with multiple test correction by the false discovery rate (FDR) of Benjamini and Hochberg [31].

\subsection{DNA Library Preparation and 454 Pyrosequencing}

DNA extraction was performed with $0.25 \mathrm{~g}$ of each soil sample using a PowerSoil DNA isolation kit (MoBio, Carlsbad, CA, USA) according to the MV method [32]. A DNA library was prepared, and pyrosequencing was performed by Macrogen Ltd. (Seoul, Korea) according to Jang et al. [33]. The FastStart High-Fidelity PCR System (Roche, Germany) was used with $20 \mathrm{ng}$ of DNA, $1 \mu \mathrm{L}$ of each forward and reverse primer $(10 \mu \mathrm{M}), 0.5 \mu \mathrm{L}$ of dNTP mix (10 mM each), $2.5 \mu \mathrm{L}$ of FastStart $10 \times$ buffer \#2, $0.25 \mu \mathrm{L}$ of FastStart Hifi Polymerase ( $5 \mathrm{U} \mu \mathrm{L}-1$ ), and molecular biology-grade water in a $25-\mu \mathrm{L}$ reaction. The $16 \mathrm{~S}$ rRNA gene (specifically, the V1 to V3 region) and the internal transcribed spacer 2 (ITS2) region were amplified with the primers 27F (5'-AGAGTTTGATCCTGGCTCAG-3')/534R (5'-ATTACCGCGGCTGCTGG-3') [34] and ITS3_KYO2 (5' -A-GATGAAGAACGYAGYRAA-3')/ITS4 (5'-B-TCCTCCGCTTATTGATATGC-3') [35] for bacterial and fungal community analysis, respectively. The thermocycler settings for bacterial amplification were as follows: initial denaturation at $95^{\circ} \mathrm{C}$ for $2 \mathrm{~min}, 30$ cycles of $95^{\circ} \mathrm{C}$ for $20 \mathrm{~s}, 56^{\circ} \mathrm{C}$ for $30 \mathrm{~s}$, and $72{ }^{\circ} \mathrm{C}$ for $60 \mathrm{~s}$ and final elongation at $72{ }^{\circ} \mathrm{C}$ for $5 \mathrm{~min}$. PCR for fungal amplication was performed with the following conditions: an initial denaturation step of $3 \mathrm{~min}$ at $94{ }^{\circ} \mathrm{C}$, followed by 35 cycles at $94{ }^{\circ} \mathrm{C}$ for $15 \mathrm{~s}, 55^{\circ} \mathrm{C}$ for $45 \mathrm{~s}$, and $72{ }^{\circ} \mathrm{C}$ for $1 \mathrm{~min}$. The reaction was concluded by a final elongation step at $72{ }^{\circ} \mathrm{C}$ for $8 \mathrm{~min}$. PCR purification was performed with Agencourt AMPure XP (Beckman Coulter, Miami, FL, USA) according to the manufacturer's manual and sent for sequencing (Macrogen Inc., Seoul, Korea). 454 pyrosequencing was performed using the GS FLX Titanium platform (454 Life Sciences, Branford, CT, USA).

\subsection{Bioinformatics Analysis}

The sequences obtained in this study were processed using QIIME v1.8.0 [36]. The primer, key, and barcode sequences were trimmed from both ends. Low-quality ( $Q V<25, \geq 1$ ambiguous base, or $>6$ homopolymers), short ( $<200 \mathrm{nt})$, and chimeric sequences were removed, leaving the sequences for analysis. Then, the sequences were clustered into operational taxonomic units (OTUs) based on a $\geq 97 \%$ similarity threshold and the average linkage method using Usearch 5.2.236. The representative sequence that was most abundant for each OTU was taxonomically assigned using the UNITE v7.2 (16.11.2017) database [37] for fungi and EzBioCloud [38] for bacteria. Rarefaction curves evaluating the sufficient sequence depth were made using QIIME, determined the depth for bacterial (2100) and fungal (5600) sequences. Alpha diversity indices were calculated in QIIME and compared between successional stages using Shapiro-Wilk test of normality, t-test, or Wilcoxon test in R. Ordination analysis of community structure was conducted based on Bray-Curtis dissimilarities for fungi and weighted UniFrac dissimilarities for bacteria. The analysis of similarities (ANOSIM) between the successional stages was performed using 9999 permutations within the sampling times (April and September) in R. Non-metric multidimensional scaling (NMDS) and environmental fitting were conducted with the environmental variables using the vegan package in R [39]. Network analysis was performed to identify the bacterial and fungal co-occurrence patterns across the successional stages. For microbial network analysis, correlations between major genera and environmental factors were tested using Spearman's rank correlation coefficient in R. Co-occurence patterns were tested based on Spearman's correlation. The correlation matrix was calculated according to the abundance of genus pairs, and significant correlations $(r \geq 0.7$, padj $<0.05)$ were retained after multiple-test correction with the FDR of Benjamini and Hochberg [31]. Network plots were drawn using the igraph package [40] in R. 


\section{Results}

\subsection{Soil Properties}

Forest succession caused marked variability in soil properties between broad-leaved-wood (late stage) and mixed-wood (early stage) forests (Figure 2). The WC, TC, TN, and pH of Odaesan forest soil exhibited successional shifts (Figure 2). The effect of forest succession on soil properties was similar to the effects on WC, TC, and TN. The soil property values increased in the broad-leaved forest, and conversely, the $\mathrm{pH}$ decreased. The organic matter quality, explained by the average $\mathrm{C} / \mathrm{N}$ ratio, was higher (more than 15\%) in the mixed-wood forest. Forest succession decreased soil acidity by up to 1.6 units compared to that in the mixed-wood forest.

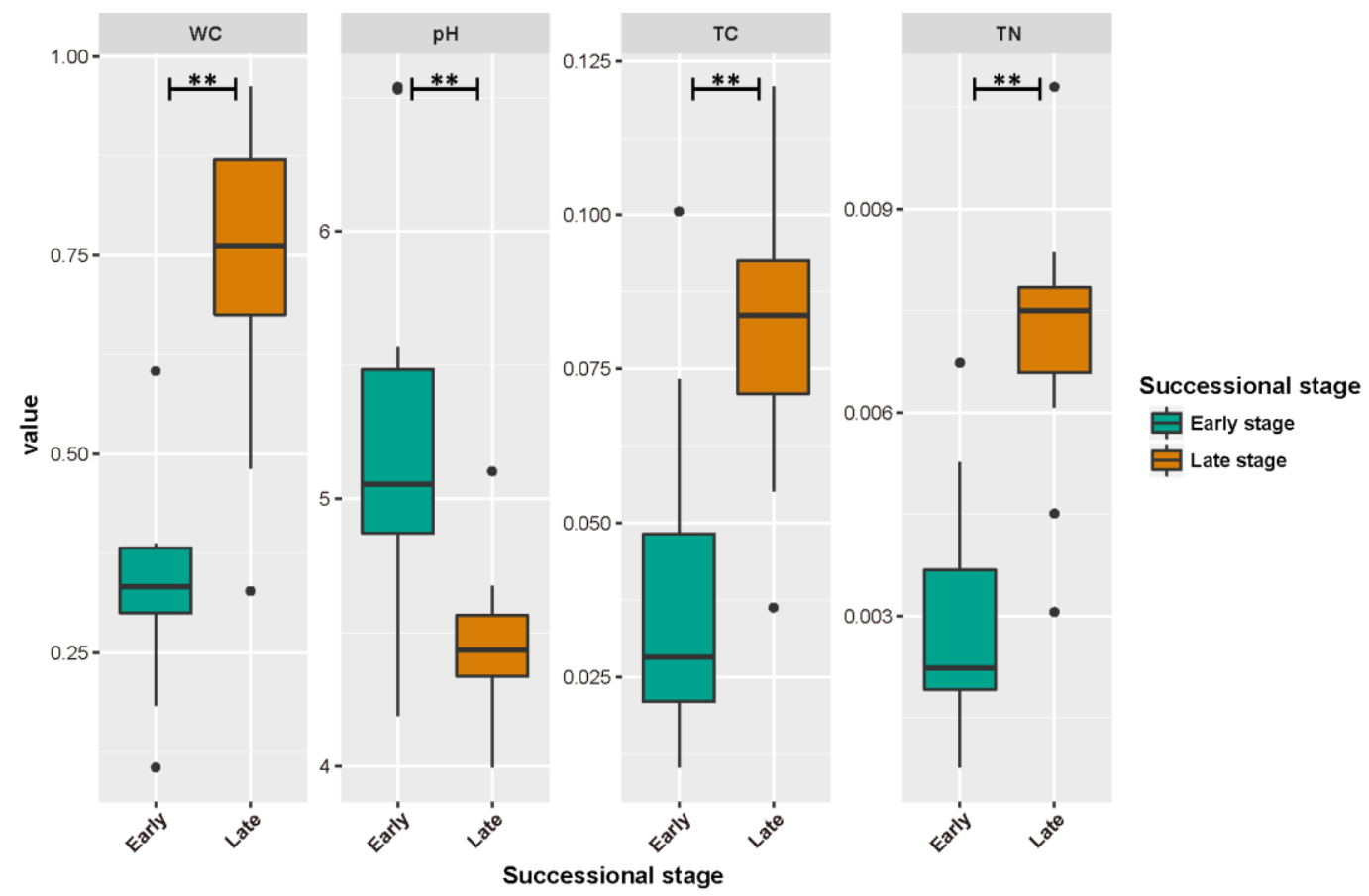

Figure 2. Comparison of soil properties between successional stages in Odaesan National Park. Significant were detected using the Wilcoxon test $\left.{ }^{* *}: p<0.01\right)$.

\subsection{Microbial Composition}

At the taxonomic level, 75,796 16S rRNA gene sequences were obtained from soil samples of both forest types. The number of reads varied from 2123 to 3980 per sample, resulting in a total of 2593 OTUs at $97 \%$ similarity. Bacterial community analysis showed that the most abundant phylum was Proteobacteria and accounted 37 and $41 \%$ of total abundances in the forest soils of early and late stage of succession, respectively (Figure 3). The relative abundances of the Pseudolabrys, Afipia, and Bradyrhizobium genera belonging to Alphaproteobacteria were greater than $25 \%$ in both types of forest soils at Odaesan National Park (Figure 3a). The relative abundances of the Pseudolabrys, Acidibacter, Koribacter, and Conexibacter genera increased with the progression of forest succession. In contrast, the abundance of the Mycobacterium and Pedomicrobium genera in the early stage of succession were higher than those in the late stage (Figure S1).

At the taxonomic level, 201,037 ITS sequences were obtained from 26 samples of both forest types. The number of reads varied from 5638 to 11,604 per sample, resulting in a total of 2448 OTUs at $97 \%$ similarity. Fungal community analysis showed that the most abundant phylum was Basidiomycota and accounted 60 and $66 \%$ in the forest soils of early and late stage of succession, respectively (Figure 3). Ascomycota exhibited an average abundance of approximately $15.2 \%$, followed by Zygomycota. The total abundances of these three major phyla accounted for 82 and $85 \%$ of the total in early and late 
stage, respectively. The sum of the relative abundances of the Saitozyma, Solicoccozyma, Trichocladium and Mortierella genera was greater than $65 \%$ in both types of forest (Figure 3b). In particular, the Saitozyma genus showed a relative abundance greater than $30 \%$. The relative abundances of the Solicoccozyma, and Gyoerffyella genera increased while the abundances of the Schizopora and Exophiala genera decreased with forest succession.
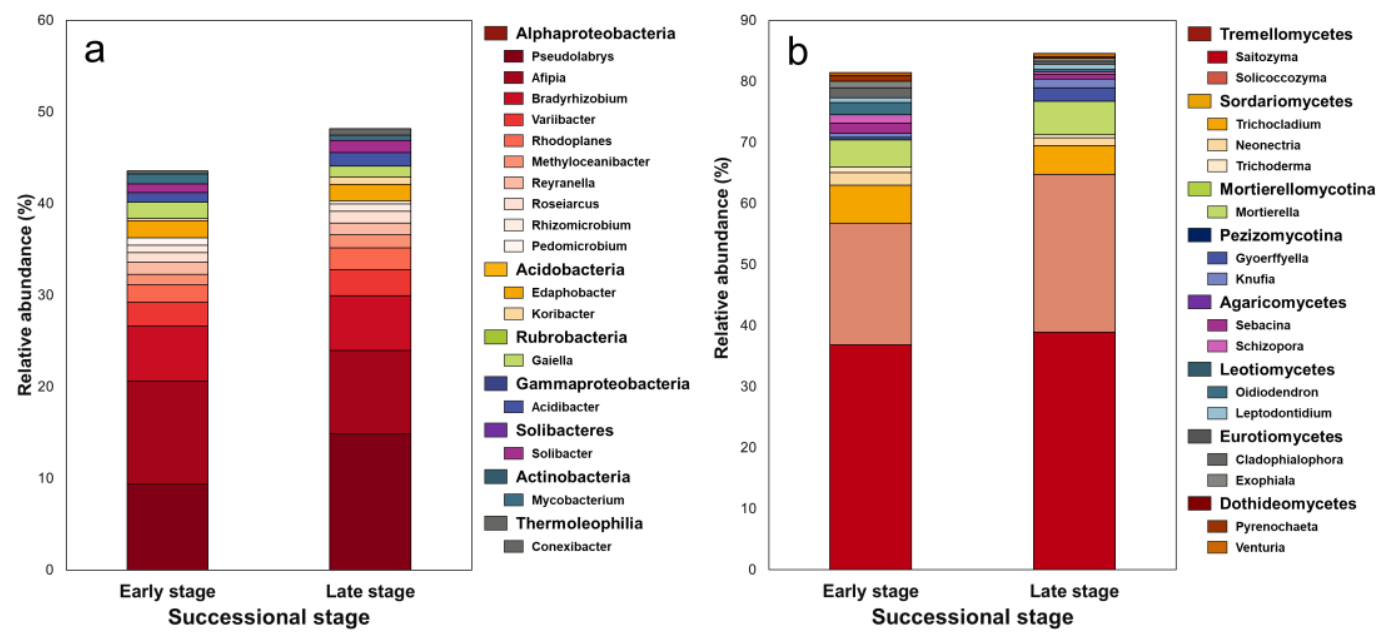

Figure 3. Changes in (a) bacterial; and (b) fungal community composition at the class and genus level between forest successional stages in Odaesan National Park.

\subsection{Microbial Diversity and Its Relationships with Environmental Variables}

There was no statistically significant difference in the richness (Chao1; $p=0.458$ ), diversity (Shannon index; $p=0.126$ ), or dominance (Simpson index; $p=0.521$ ) of the bacterial community between the stages of forest succession (Table S1). In contrast to that in the bacterial community, the number of observed OTUs in the fungal community was higher $(p=0.045)$ in the early stage of succession (Table S1). There was no significant difference in richness $(p=0.068)$, diversity $(p=0.154)$, or dominance ( $p=0.21$ ) for the fungal community. By analyzing the beta diversity of each bacterial community through ordination analysis based on weighted UniFrac dissimilarities, we detected a distinct shift in the bacterial community as succession proceeded by ANOSIM test $(\mathrm{R}=0.6143$; $p=0.0001$ ), and environmental fitting analysis with NMDS revealed that elevation, WC, TC, TN, and $\mathrm{pH}$ were significant factors distinguishing the bacterial communities (Figure 4a and Table S2). Among the bacterial genera, Edaphobacter and Pedomicrobium were significantly related to $\mathrm{pH}$, while Reyranella was significantly related to TC (Figure 5a). When the beta diversity of the fungal community was analyzed by ANOSIM, the distribution of fungal communities was also clearly dependent on the stage of succession ( $\mathrm{R}=0.1314 ; p=0.023$ ) (Figure $4 \mathrm{~b}$ ). In addition, envfit analysis revealed significant influences of soil properties on the fungal community (Table S2). These results were similar to those for the bacterial community. Among the fungal genera, Mortierella showed significant relationships with elevation and WC, and Gyoerffyella showed a significant relationship with WC (Figure 5b). 

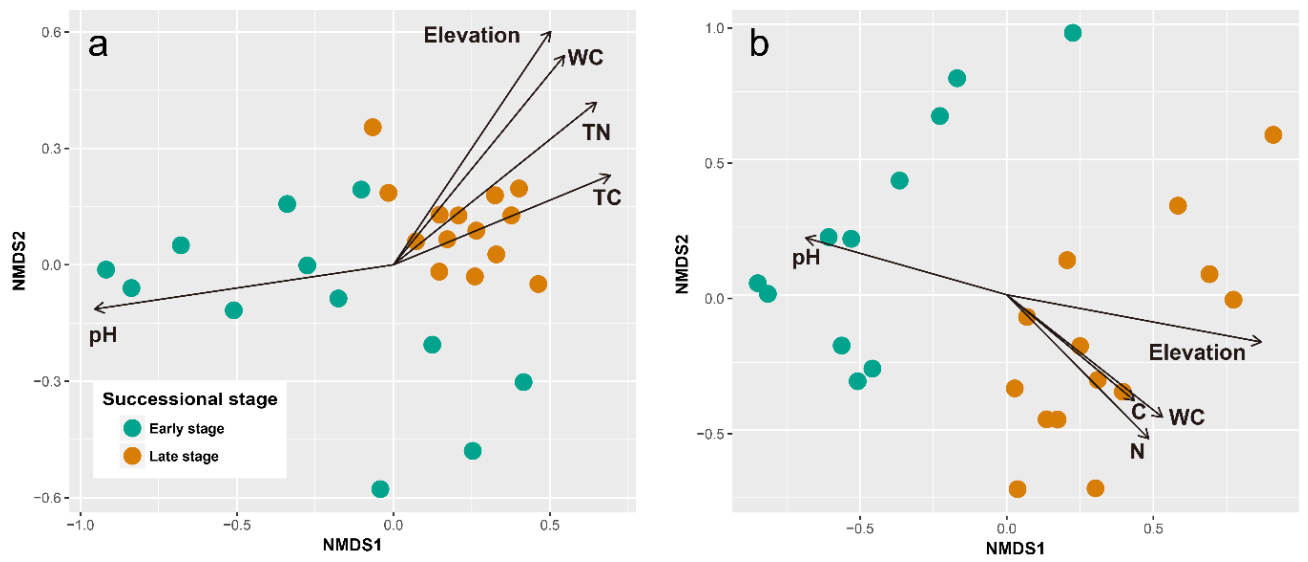

Figure 4. Non-metric multidimensional scaling (NMDS) plot derived from (a) the weighted UniFrac dissimilarities for the bacterial community; and (b) the Bray-Curtis dissimilarities for the fungal community from soil samples in Odaesan National Park.

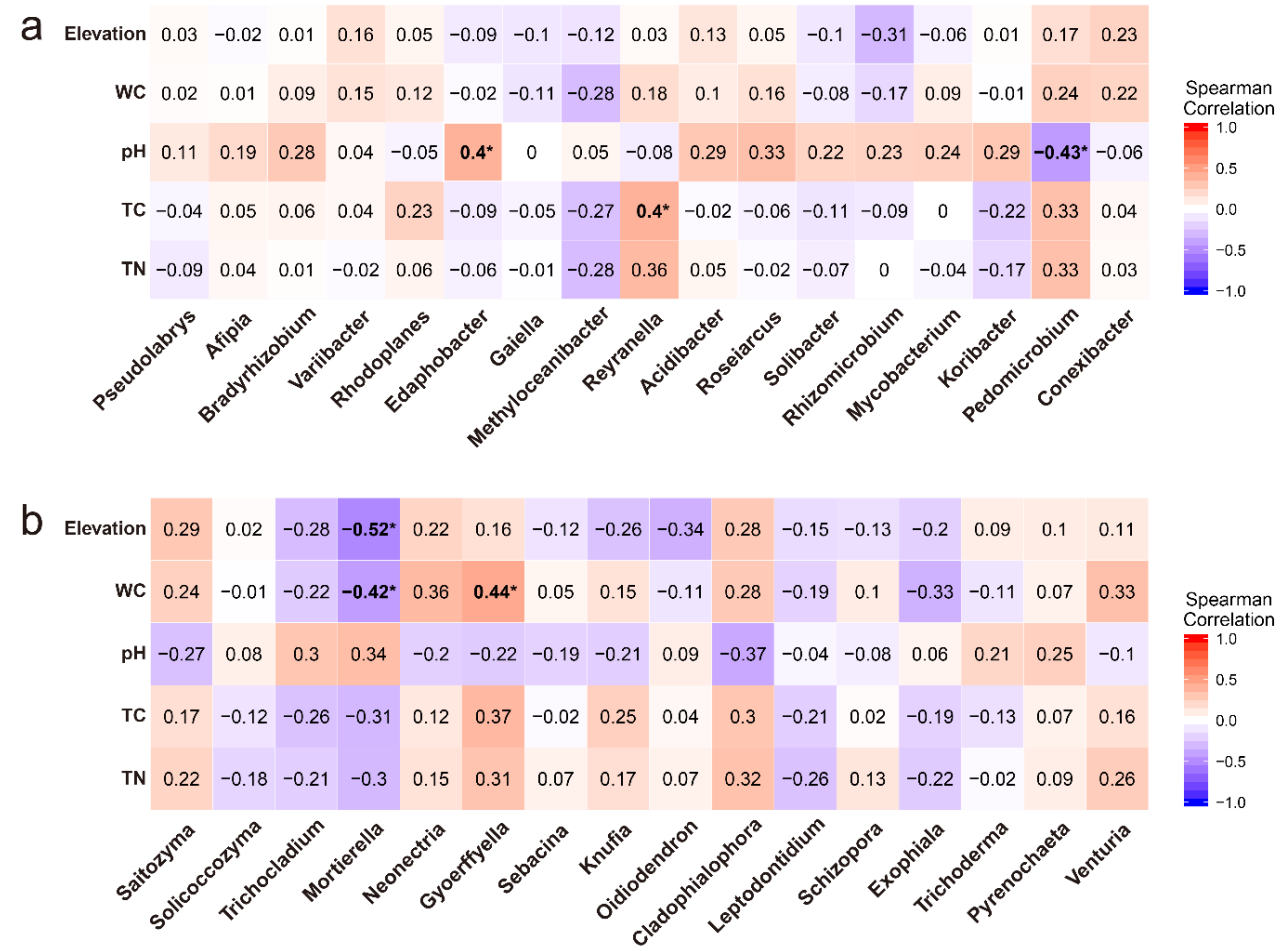

Figure 5. Relationships between soil properties and the relative abundances of major (a) bacterial; and (b) fungal genera in both successional stages. Statistical significance $\left.{ }^{*}\right)$ was defined as $p<0.05$.

\subsection{Microbial Networks}

As shown in Figure 6, the microbial networks were determined based on correlations between microbial genus abundances at each successional stage. In the early successional stage, the network consisted of four groups including hybrid or separate compartments of bacterial and fungal taxa. In particular, Mortierella spp. formed a network with four fungal genera, and Roseiarcus spp. formed a network with three taxa. In the late stage, the microbial network became simpler. A total of four groups of networks were constructed, but each group consisted of only two microbial genera. 


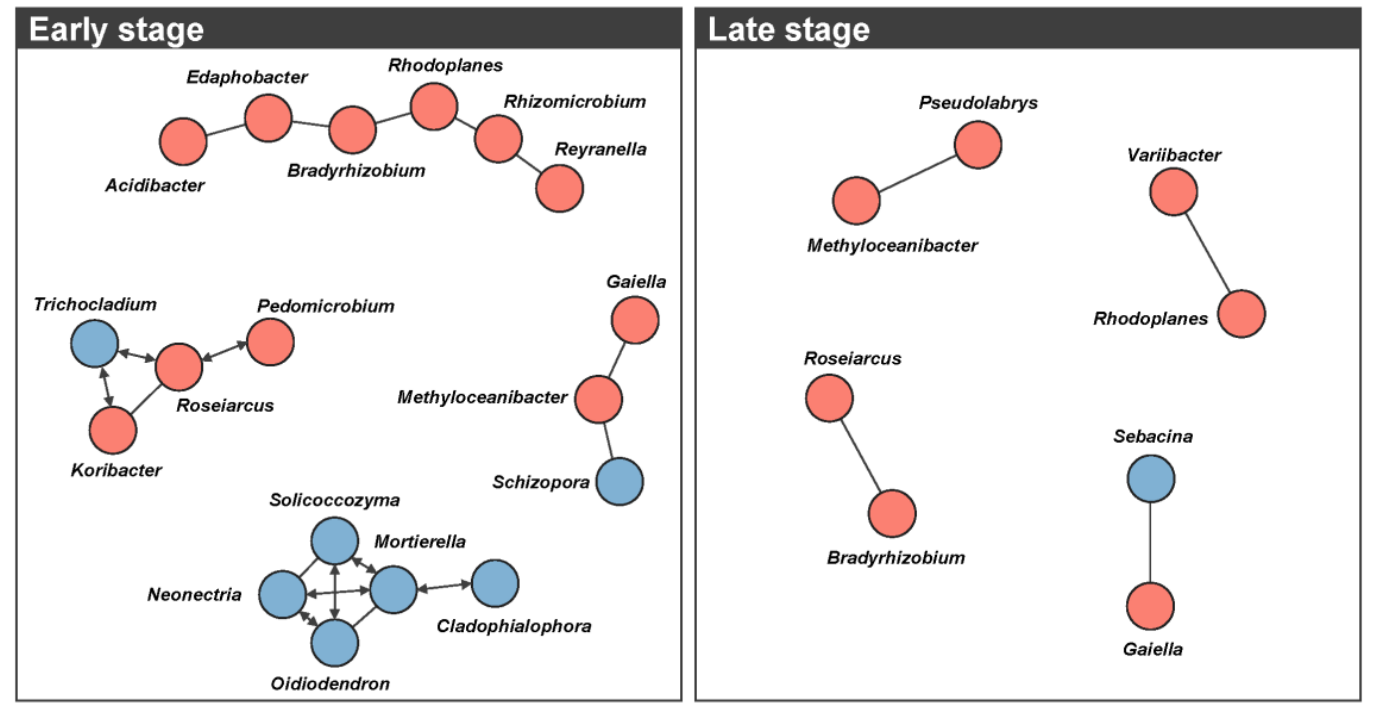

Figure 6. Microbial networks constructed based on correlations between bacterial (red dots) and fungal (blue dots) genus abundances at each successional stage.

\section{Discussion}

The bacterial and fungal DNA extracted from forest soil was analyzed to investigate the differences in the microbial community caused by forest succession in Odaesan National Park. In general, the microbial community responds more quickly to environmental disturbances causing ecological succession than to plants, animals, and insects [41,42]. Because the phylogenetic diversity of microorganisms is high and is closely associated with geochemical properties, it is important to monitor and analyze the microbial community as a sensitive index during forest succession [43]. Therefore, in this study, variation in forest soil and the microbial community according to forest succession was analyzed, and we focused on the relationships between soil properties and the microbial community.

With succession, the vegetation in Odaesan National Park changed from P. densiflora to Q. mongolica and $Q$. variabilis, exhibiting forest succession from an early stage (mixed-wood forest) to a late stage (broad-leaved forest) [28]. Forest succession from the early stage to the late stage also greatly changed the properties of the forest soil (Figure 2). First, the average WC of the soil was higher in the late stage forest. This result could be explained by late-stage wood having a higher leaf area index than mixed- wood, which was able to block sunlight and shade the surface of soil resulting in wetter soil conditions, but also be caused by differences in altitude, since late-stage forests were located in higher altitudes [44,45].

Forest succession generally leads to soil improvement and increased TC and TN contents [46]. In this study, the TC and TN concentrations in forest soils were higher in the late stage than in the early stage (Figure 2). As the forest develops, the microbial community adapts to the substrate and decomposes leaves and branches to increase the nutrient concentration in the soil [47]. When the nitrogen and carbon availability in the soil increases, inorganic nitrogen is absorbed by the plants, and the nitrogen concentration in the leaves also increases so that when the leaves are dropped, they again become a useful substrate for the microorganisms and increase nutrient availability [48,49]. Additionally, as the microbial community develops, the carbon content derived from microbial biomass also increases, thereby increasing the TC content of the soil [48]. However, the alpha diversity of the microbial communities in this study did not show any difference in richness according to successional stage (Table S1). Another reason for the high TC and TN concentrations in late-stage forests may be the high moisture content. Soil moisture affects not only soil structure but also the transport of substances and nutrients and microbial activity [50,51]. In soil with low water solubility, microorganismal cells have a low WC, which can prevent microbial enzymes from binding to the substrate and thus decrease microbial activity [50]. As a result, the degradation of organic matter in the soil is restricted, decreasing 
the soil nutrient concentration. In contrast, the higher WC at the late stage may have contributed to the high TC and TN contents by increasing nutrient circulation and the activities of the enzymes produced by microorganisms [52]. On the other hand, the $\mathrm{C} / \mathrm{N}$ ratio of the forest soil in Odaesan National Park ranged from 9 to 15 , and the ratio in the soil samples from the late successional stage was slightly lower than that in the soil samples from the early stage. Generally, if the $\mathrm{C} / \mathrm{N}$ ratio is less than 15 , organic matter is mineralized, and nitrogen can be used effectively $[53,54]$. The relatively low $\mathrm{C} / \mathrm{N}$ ratio in late stage forest soils may be related to the type of vegetation. At the early stage of succession, the litter produced contained a lignified and aromatic substrate with a high $\mathrm{C} / \mathrm{N}$ ratio [55]. Thus, the $\mathrm{C} / \mathrm{N}$ ratio of the soil was also considered to be high. As forest succession progresses, overall plant biomass increases, and the increased root area causes a higher WC in forest soil and a greater abundance of symbiotic microorganisms [46]. Soils in more developed forests have higher TC and TN concentrations due to the quantitative increase in microbial biomass and the development of aerial parts of trees [46]. Although our results did not show any increase in the richness of the microbial community in the developed forest (Table S1), the microbial community may have contributed to the degradation and circulation of organic matter, thereby increasing the TC and TN concentrations.

The structure and composition of the microbial community differed with succession of the forest from mixed-wood forest to broad-leaved forest (Figures 3 and 4). According to forest successional stage, the microbial communities showed different compositions and structures, which were well described by NMDS analysis, revealing a difference in the community composition of the microbial communities between the two successional stages (Figure 4). These results effectively support the fundamental concept that soil and vegetation properties can induce a variety of microhabitats, allowing various microorganisms to coexist [56]. Forest succession causes a change in vegetation, which in turn causes changes in the soil in which the vegetation grows and alters the microbial community [57]. The plant community, which is altered by succession, exhibits regional differences (root depth, bark, leaf shade area, and tree density) and ultimately has a significant impact on microbial community structure [58]. Soil WC, TC, TN, C/N ratio, and $\mathrm{pH}$ changed in response to succession, and the bacterial and fungal taxa that were correlated with soil properties differed in abundance according to successional stage, eventually altering microbial community structure. Interestingly, most taxa that showed different relative abundances as succession progressed exhibited no significant correlations with soil properties. This result indicates that other environmental factors determined the microbial habitat and affected the shift in the microbial community. The most prominent factor was the interaction between trees and the shifted taxa. Among the dominant taxa in each stage, the genera whose abundance was significantly changed by succession were Pseudolabrys and Solicoccozyma, both of which showed a high abundance in the late stage. The genus Pseudolabrys is mainly found in soil and belongs to the Rhizobiales, which fix nitrogen and are symbiotic with plant roots $[59,60]$. Solicoccozyma is a genus of basidiomycetous yeast that is mainly found in soil and frequently produces thick polysaccharide capsules and low-weight aromatic compounds [60]. Although none of these genus has been reported to have a symbiotic relationship with Quercus spp., they are expected to play a major role in the carbon and nitrogen cycles, and their significantly higher abundance in the late stage can serve as a bioindicator for monitoring microbial succession.

We also investigated microbial networks to estimate the effects of forest succession on the relationships of microorganisms and microbial ecology (Figure 6). Our findings suggest that Odaesan National Park has a large and tight network, implicating stronger coupling between microbes in driving nutrient cycles. The microbial networks were different between the early and late stages of the forest. The number of taxa constituting the microbial network was higher during the early stage, and the relationships between the microbial genera were complex, which contrasts with the general view that microbial networks become better developed with environmental succession [61]. These results were probably due to the early stage being composed of mixed-wood, which provided various substrates to the microbes and resulted in a larger number of microorganisms participating in organic matter decomposition, nutrient circulation, and complex networks. The simplification 
of the microbial network might also have occurred because the environmental conditions in the late stage were stabilized and simplified via the succession process. Meanwhile, the relationships between taxon pairs were independent of the relationships between the microorganisms and the soil properties (Figures 5 and 6). Although soil properties, such as organic matter, $\mathrm{pH}$, and moisture, evidently determine microorganismal growth, microbial abundance and networks can also be regulated via competition, various metabolites, antagonism, niche preferences, and other factors $[62,63]$. Consequently, various interactions between microorganisms and the nutrient composition of the forest soil determined microbial network composition, resulting in the formation of the microbial network unique to Odaesan National Park.

\section{Conclusions}

We investigated the changes in forest soil characteristics and microbial community structure between different successional stages in Odaesan National Park. Among the soil properties, elecation, $\mathrm{WC}, \mathrm{TC}, \mathrm{TN}$, and $\mathrm{pH}$ were significantly different between the successional stages, indicating that the forest was more developed in the late successional stage and that the soil was fertile. The structure and composition of the microbial community clearly differed between the successional stages. Although there was no significant difference in the richness or diversity of the microbial community, the difference in community composition was confirmed by NMDS analysis and the ANOSIM. Changes in these microbial communities were considered to be due to taxonomic groups being correlated with soil properties, including elevation, $\mathrm{WC}, \mathrm{TC}, \mathrm{TN}$, and $\mathrm{pH}$, which significantly affected the microbial community distribution. In addition, various microbial taxa formed a network that depended on the correlations at each successional stage. The composition of the network was not consistent with the group showing similar tendencies in response to changes in soil properties. The microbial network was affected by not only the correlations with soil properties but also the metabolites produced by various strains and the enzyme profile aiding nutrition acquisition. The results of this study suggest that forest succession has a strong influence on the soil properties, microbial community structure, and microbial networks in Odaesan National Park, which sheds light on microbial ecosystems under successional change.

Supplementary Materials: The following are available online at http://www.mdpi.com/2071-1050/12/11/4795/s1: Table S1, Geographic information and alpha diversity analysis of soil samples from Odaesan National Park.

Author Contributions: Conceptualization, H.L., S.-Y.O., and Y.J.; methodology, Y.M.L., Y.J., and S.J.; software, H.L. and S.-Y.O.; validation, Y.W.L. and J.-J.K.; formal analysis, H.L. and S.-Y.O.; investigation, H.L., Y.M.L., Y.J., and S.J.; data curation, H.L. and S.-Y.O.; writing-original draft preparation, H.L. and Y.M.L.; writing-review and editing, Y.W.L. and J.-J.K.; visualization, H.L. and S.-Y.O.; supervision, Y.W.L., C.K., and J.-J.K.; project administration, C.K.; funding acquisition, J.-J.K. All authors have read and agreed to the published version of the manuscript.

Funding: This work was supported by a Korea University Grant and a National Research Foundation of Korea (NRF) grant funded by the Korean government (MSIP) (NRF-2019R1I1A1A01060989). Additional funding was provided by the project for the survey and excavation of Korean indigenous species of the National Institute of Biological Resources [NIBR201902113].

Conflicts of Interest: The authors declare no conflicts of interest.

\section{References}

1. Wooley, J.C.; Ye, Y.Z. Metagenomics: Facts and artifacts, and computational challenges. J. Comput. Sci. Technol. 2010, 25, 71-81. [CrossRef] [PubMed]

2. Lee, H.; Lee, D.W.; Kwon, S.L.; Heo, Y.M.; Jang, S.; Kwon, B.-O.; Khim, J.S.; Kim, G.-H.; Kim, J.-J. Importance of functional diversity in assessing the recovery of the microbial community after the Hebei Spirit oil spill in Korea. Environ. Int. 2019, 128, 89-94. [CrossRef] [PubMed]

3. Igalavithana, A.D.; Lee, S.S.; Niazi, N.K.; Lee, Y.-H.; Kim, K.H.; Park, J.-H.; Moon, D.H.; Ok, Y.S. Assessment of soil health in urban agriculture: Soil enzymes and microbial properties. Sustainability Basel 2017, 9, 310. [CrossRef] 
4. Birgander, J.; Rousk, J.; Olsson, P.A. Comparison of fertility and seasonal effects on grassland microbial communities. Soil Biol. Biochem. 2014, 76, 80-89. [CrossRef]

5. Heo, Y.M.; Lee, H.; Kim, K.; Kwon, S.L.; Park, M.Y.; Kang, J.E.; Kim, G.-H.; Kim, B.S.; Kim, J.-J. Fungal diversity in intertidal mudflats and abandoned solar salterns as a source for biological resources. Mar. Drugs 2019, 17, 601. [CrossRef]

6. Li, X.Z.; Rui, J.P.; Mao, Y.J.; Yannarell, A.; Mackie, R. Dynamics of the bacterial community structure in the rhizosphere of a maize cultivar. Soil Biol. Biochem. 2014, 68, 392-401. [CrossRef]

7. Puissant, J.; Cecillon, L.; Mills, R.T.E.; Robroek, B.J.M.; Gavazov, K.; De Danieli, S.; Spiegelberger, T.; Buttler, A.; Brun, J.J. Seasonal influence of climate manipulation on microbial community structure and function in mountain soils. Soil Biol. Biochem. 2015, 80, 296-305. [CrossRef]

8. Tas, N.; Prestat, E.; McFarland, J.W.; Wickland, K.P.; Knight, R.; Berhe, A.A.; Jorgenson, T.; Waldrop, M.P.; Jansson, J.K. Impact of fire on active layer and permafrost microbial communities and metagenomes in an upland Alaskan boreal forest. ISME J. 2014, 8, 1904-1919. [CrossRef]

9. Zhang, X.F.; Xu, S.J.; Li, C.M.; Zhao, L.; Feng, H.Y.; Yue, G.Y.; Ren, Z.W.; Cheng, G.D. The soil carbon/nitrogen ratio and moisture affect microbial community structures in alkaline permafrost-affected soils with different vegetation types on the Tibetan plateau. Res. Microbiol. 2014, 165, 128-139. [CrossRef]

10. Luyssaert, S.; Jammet, M.; Stoy, P.C.; Estel, S.; Pongratz, J.; Ceschia, E.; Churkina, G.; Don, A.; Erb, K.; Ferlicoq, M.; et al. Land management and land-cover change have impacts of similar magnitude on surface temperature. Nat. Clim. Chang. 2014, 4, 389-393. [CrossRef]

11. Schuur, E.A.G.; McGuire, A.D.; Schadel, C.; Grosse, G.; Harden, J.W.; Hayes, D.J.; Hugelius, G.; Koven, C.D.; Kuhry, P.; Lawrence, D.M.; et al. Climate change and the permafrost carbon feedback. Nature 2015, 520, 171-179. [CrossRef] [PubMed]

12. Verges, A.; Steinberg, P.D.; Hay, M.E.; Poore, A.G.B.; Campbell, A.H.; Ballesteros, E.; Heck, K.L.; Booth, D.J.; Coleman, M.A.; Feary, D.A.; et al. The tropicalization of temperate marine ecosystems: Climate-mediated changes in herbivory and community phase shifts. Proc. R. Soc. B Biol. Sci. 2014, 281. [CrossRef] [PubMed]

13. Garnier, E.; Cortez, J.; Billes, G.; Navas, M.L.; Roumet, C.; Debussche, M.; Laurent, G.; Blanchard, A.; Aubry, D.; Bellmann, A.; et al. Plant functional markers capture ecosystem properties during secondary succession. Ecology 2004, 85, 2630-2637. [CrossRef]

14. Pastor, J.; Post, W.M. Influence of climate, soil-moisture, and succession on forest carbon and nitrogen cycles. Biogeochemistry 1986, 2, 3-27. [CrossRef]

15. Turner, M.G.; Baker, W.L.; Peterson, C.J.; Peet, R.K. Factors influencing succession: Lessons from large, infrequent natural disturbances. Ecosystems 1998, 1, 511-523. [CrossRef]

16. Elliott, K.J.; Boring, L.R.; Swank, W.T.; Haines, B.R. Successional changes in plant species diversity and composition after clearcutting a Southern Appalachian watershed. For. Ecol. Manag. 1997, 92, 67-85. [CrossRef]

17. Reynolds, H.L.; Packer, A.; Bever, J.D.; Clay, K. Grassroots ecology: Plant-microbe-soil interactions as drivers of plant community structure and dynamics. Ecology 2003, 84, 2281-2291. [CrossRef]

18. Liu, Y.C.; Dong, Q.; Wu, C.; Zhou, X.H.; Shi, H.C. Study of the succession of microbial communities for sulfur cycle response to ecological factors change in sediment of sewage system. Environ. Sci. Pollut. Res. 2015, 22, 9250-9259. [CrossRef]

19. Lozano, Y.M.; Hortal, S.; Armas, C.; Pugnaire, F.I. Interactions among soil, plants, and microorganisms drive secondary succession in a dry environment. Soil Biol. Biochem. 2014, 78, 298-306. [CrossRef]

20. Scheu, S. Changes in microbial nutrient status during secondary succession and its modification by earthworms. Oecologia 1990, 84, 351-358. [CrossRef]

21. Zhou, Z.H.; Wang, C.K.; Jiang, L.F.; Luo, Y.Q. Trends in soil microbial communities during secondary succession. Soil Biol. Biochem. 2017, 115, 92-99. [CrossRef]

22. Kardol, P.; Todd, D.E.; Hanson, P.J.; Mulholland, P.J. Long-term successional forest dynamics: Species and community responses to climatic variability. J. Veg. Sci. 2010, 21, 627-642. [CrossRef]

23. Cong, J.; Liu, X.D.; Lu, H.; Xu, H.; Li, Y.D.; Deng, Y.; Li, D.Q.; Zhang, Y.G. Available nitrogen is the key factor influencing soil microbial functional gene diversity in tropical rainforest. BMC Microbiol. 2015, 15. [CrossRef]

24. Gao, C.; Shi, N.N.; Liu, Y.X.; Zheng, Y.; Ding, Q.; Mi, X.C.; Ma, K.P.; Wubet, T.; Buscot, F.; Guo, L.D. Host plant richness explains diversity of ectomycorrhizal fungi: Response to the comment of Tedersoo et al. (2014). Mol. Ecol. 2014, 23, 996-999. [CrossRef] 
25. Jang, Y.; Jang, S.; Lee, J.; Lee, H.; Lim, Y.W.; Kim, C.; Kim, J.J. Diversity of Wood-Inhabiting Polyporoid and Corticioid Fungi in Odaesan National Park, Korea. Mycobiology 2016, 44, 217-236. [CrossRef]

26. Lee, K.; Kim, S.; Shin, Y.; Choung, Y. Spatial pattern and association of tree species in a mixed Abies holophylla-broadleaved deciduous forest in Odaesan National Park. J. Plant Biol. 2012, 55, 242-250. [CrossRef]

27. Park, Y.; Kim, J.; Jang, T.; Chae, H.; Takami, Y. Local climate mediates spatial and temporal variation in carabid beetle communities in three forests in Mount Odaesan, Korea. Ecol. Entomol. 2017, 42, 184-194. [CrossRef]

28. Byun, D.; Lee, H.; Kim, C. Vegetation pattern and successional sere in the forest of Mt. Odae. Korean J. Ecololgy (Korea Repub.) 1998, 21, 283-290.

29. Mosandl, R.; Kleinert, A. Development of oaks (Quercus petraea (Matt.) Liebl.) emerged from bird-dispersed seeds under old-growth pine (Pinus silvestris L.) stands. For. Ecol. Manag. 1998, 106, 35-44. [CrossRef]

30. González-Espinosa, M.; Ramírez-Marcial, N.; Galindo-Jaimes, L. Secondary succession in montane pine-oak forests of Chiapas, Mexico. In Ecology and Conservation of Neotropical Montane Oak Forests; Springer: Berlin/Heidelberg, Germany, 2006; pp. 209-221.

31. Benjamini, Y.; Hochberg, Y. Controlling the false discovery rate: A practical and powerful approach to multiple testing. J. R. Stat. Soc. Ser. B (Methodol.) 1995, 57, 289-300. [CrossRef]

32. Sagova-Mareckova, M.; Cermak, L.; Novotna, J.; Plhackova, K.; Forstova, J.; Kopecky, J. Innovative methods for soil DNA purification tested in soils with widely differing characteristics. Appl. Environ. Microbiol. 2008, 74, 2902-2907. [CrossRef]

33. Jang, Y.; Jang, S.; Min, M.; Hong, J.-H.; Lee, H.; Lee, H.; Lim, Y.W.; Kim, J.-J. Comparison of the diversity of basidiomycetes from dead wood of the Manchurian fir (Abies holophylla) as evaluated by fruiting body collection, mycelial isolation, and 454 sequencing. Microb. Ecol. 2015, 70, 634-645. [CrossRef]

34. Sundberg, C.; Al-Soud, W.A.; Larsson, M.; Alm, E.; Yekta, S.S.; Svensson, B.H.; Sørensen, S.J.; Karlsson, A. 454 pyrosequencing analyses of bacterial and archaeal richness in 21 full-scale biogas digesters. FEMS Microbiol. Ecol. 2013, 85, 612-626. [CrossRef]

35. Toju, H.; Tanabe, A.S.; Yamamoto, S.; Sato, H. High-coverage ITS primers for the DNA-based identification of ascomycetes and basidiomycetes in environmental samples. PloS ONE 2012, 7, e40863. [CrossRef]

36. Caporaso, J.G.; Kuczynski, J.; Stombaugh, J.; Bittinger, K.; Bushman, F.D.; Costello, E.K.; Fierer, N.; Pena, A.G.; Goodrich, J.K.; Gordon, J.I.; et al. QIIME allows analysis of high-throughput community sequencing data. Nat. Methods 2010, 7, 335-336. [CrossRef]

37. Kõljalg, U.; Larsson, K.H.; Abarenkov, K.; Nilsson, R.H.; Alexander, I.J.; Eberhardt, U.; Erland, S.; Høiland, K.; Kjøller, R.; Larsson, E. UNITE: A database providing web-based methods for the molecular identification of ectomycorrhizal fungi. New Phytol. 2005, 166, 1063-1068. [CrossRef]

38. Yoon, S.-H.; Ha, S.-M.; Kwon, S.; Lim, J.; Kim, Y.; Seo, H.; Chun, J. Introducing EzBioCloud: A taxonomically united database of $16 \mathrm{~S}$ rRNA gene sequences and whole-genome assemblies. Int. J. Syst. Evol. Microbiol. 2017, 67, 1613. [CrossRef]

39. Oksanen, J.; Blanchet, F.G.; Kindt, R.; Legendre, P.; Minchin, P.R.; O’hara, R.; Simpson, G.L.; Solymos, P.; Stevens, M.H.H.; Wagner, H. Package 'vegan'. Community Ecol. Package Version 2013, 2, 1-295.

40. Csardi, G.; Nepusz, T. The igraph software package for complex network research. InterJournal Complex Syst. 2006, 1695, 1-9.

41. Findlay, R.H.; Trexler, M.B.; Guckert, J.B.; White, D.C. Laboratory study of disturbance in marine-sediments: Response of a microbial community. Mar. Ecol. Prog. Ser. 1990, 62, 121-133. [CrossRef]

42. Lee, H.; Heo, Y.M.; Kwon, S.L.; Yoo, Y.; Lee, A.H.; Kwon, B.-O.; Kim, G.-H.; Khim, J.S.; Kim, J.-J. Recovery of the benthic bacterial community in coastal abandoned saltern requires over 35 years: A comparative case study in the Yellow Sea. Environ. Int. 2020, 135, 105412. [CrossRef] [PubMed]

43. Webster, N.S.; Webb, R.I.; Ridd, M.J.; Hill, R.T.; Negri, A.P. The effects of copper on the microbial community of a coral reef sponge. Environ. Microbiol. 2001, 3, 19-31. [CrossRef] [PubMed]

44. Rodriguez-Iturbe, I.; Isham, V.; Cox, D.R.; Manfreda, S.; Porporato, A. Space-time modeling of soil moisture: Stochastic rainfall forcing with heterogeneous vegetation. Water Resour. Res. 2006, 42. [CrossRef]

45. Yang, L.; Wei, W.; Chen, L.D.; Chen, W.L.; Wang, J.L. Response of temporal variation of soil moisture to vegetation restoration in semi-arid Loess Plateau, China. Catena 2014, 115, 123-133. [CrossRef] 
46. Gamboa, A.M.; Hidalgo, C.; De Leon, F.; Etchevers, J.D.; Gallardo, J.F.; Campo, J. Nutrient addition differentially affects soil carbon sequestration in secondary tropical dry forests: Early- versus late-succession stages. Restor. Ecol. 2010, 18, 252-260. [CrossRef]

47. Dijkstra, F.A.; Bader, N.E.; Johnson, D.W.; Cheng, W.X. Does accelerated soil organic matter decomposition in the presence of plants increase plant $\mathrm{N}$ availability? Soil Biol. Biochem. 2009, 41, 1080-1087. [CrossRef]

48. Aponte, C.; Maranon, T.; Garcia, L.V. Microbial C, N and P in soils of Mediterranean oak forests: Influence of season, canopy cover and soil depth. Biogeochemistry 2010, 101, 77-92. [CrossRef]

49. Bernhardt-Romermann, M.; Kudernatsch, T.; Pfadenhauer, J.; Kirchner, M.; Jakobi, G.; Fischer, A. Long-term effects of nitrogen deposition on vegetation in a deciduous forest near Munich, Germany. Appl. Veg. Sci. 2007, 10, 399-406. [CrossRef]

50. Geisseler, D.; Horwath, W.R.; Scow, K.M. Soil moisture and plant residue addition interact in their effect on extracellular enzyme activity. Pedobiologia 2011, 54, 71-78. [CrossRef]

51. Castaño, C.; Lindahl, B.D.; Alday, J.G.; Hagenbo, A.; Martínez de Aragón, J.; Parladé, J.; Pera, J.; Bonet, J.A. Soil microclimate changes affect soil fungal communities in a Mediterranean pine forest. New Phytol. 2018, 220, 1211-1221. [CrossRef]

52. Steinweg, J.M.; Dukes, J.S.; Wallenstein, M.D. Modeling the effects of temperature and moisture on soil enzyme activity: Linking laboratory assays to continuous field data. Soil Biol. Biochem. 2012, 55, 85-92. [CrossRef]

53. Aulakh, M.S.; Aulakh, N.S. Interactions of nitrogen with other nutrients and water: Effect on crop yield and quality, nutrient use efficiency, carbon sequestration, and environmental pollution. Adv. Agron. 2005, 86, 341-409. [CrossRef]

54. Lafleur, B.; Hooper-Bui, L.M.; Mumma, E.P.; Geaghan, J.P. Soil fertility and plant growth in soils from pine forests and plantations: Effect of invasive red imported fire ants Solenopsis invicta (Buren). Pedobiologia 2005, 49, 415-423. [CrossRef]

55. Noh, N.J.; Son, Y.; Lee, S.K.; Seo, K.W.; Heo, S.J.; Yi, M.J.; Park, P.S.; Kim, R.H.; Son, Y.M.; Lee, K.H. Carbon and nitrogen storage in an age-sequence of Pinus densiflora stands in Korea. Sci. China Life Sci. 2010, 53, 822-830. [CrossRef]

56. Lauber, C.L.; Strickland, M.S.; Bradford, M.A.; Fierer, N. The influence of soil properties on the structure of bacterial and fungal communities across land-use types. Soil Biol. Biochem. 2008, 40, 2407-2415. [CrossRef]

57. Castro, H.F.; Classen, A.T.; Austin, E.E.; Norby, R.J.; Schadt, C.W. Soil Microbial Community Responses to Multiple Experimental Climate Change Drivers. Appl. Environ. Microbiol. 2010, 76, 999-1007. [CrossRef]

58. Bezemer, T.M.; Lawson, C.S.; Hedlund, K.; Edwards, A.R.; Brook, A.J.; Igual, J.M.; Mortimer, S.R.; Van der Putten, W.H. Plant species and functional group effects on abiotic and microbial soil properties and plant-soil feedback responses in two grasslands. J. Ecol. 2006, 94, 893-904. [CrossRef]

59. Kämpfer, P.; Young, C.-C.; Arun, A.; Shen, F.-T.; Jäckel, U.; Rossello-Mora, R.; Lai, W.-A.; Rekha, P. Pseudolabrys taiwanensis gen. nov., sp. nov., an alphaproteobacterium isolated from soil. Int. J. Syst. Evol. Microbiol. 2006, 56, 2469-2472.

60. Liu, X.-Z.; Wang, Q.-M.; Göker, M.; Groenewald, M.; Kachalkin, A.; Lumbsch, H.T.; Millanes, A.; Wedin, M.; Yurkov, A.; Boekhout, T. Towards an integrated phylogenetic classification of the Tremellomycetes. Stud. Mycol. 2015, 81, 85-147. [CrossRef]

61. Cong, J.; Yang, Y.F.; Liu, X.D.; Lu, H.; Liu, X.; Zhou, J.Z.; Li, D.Q.; Yin, H.Q.; Ding, J.J.; Zhang, Y.G. Analyses of soil microbial community compositions and functional genes reveal potential consequences of natural forest succession. Sci. Rep. 2015, 5. [CrossRef]

62. Bonfante, P.; Anca, I.A. Plants, Mycorrhizal Fungi, and Bacteria: A Network of Interactions. Annu. Rev. Microbiol. 2009, 63, 363-383. [CrossRef] [PubMed]

63. Hoppe, B.; Kahl, T.; Karasch, P.; Wubet, T.; Bauhus, J.; Buscot, F.; Kruger, D. Network analysis reveals ecological links between N-fixing bacteria and wood-decaying fungi. PloS ONE 2014, 9, e88141. [CrossRef] [PubMed]

(C) 2020 by the authors. Licensee MDPI, Basel, Switzerland. This article is an open access article distributed under the terms and conditions of the Creative Commons Attribution (CC BY) license (http://creativecommons.org/licenses/by/4.0/). 